\title{
PALEOENVIRONMENTAL AND ARCHEOLOGICAL SIGNIFICANCE OF ALLUVIAL PLACERS OF THE BRAZILIAN AMAZON
}

\author{
A.T.C.Veiga ${ }^{1}$
}

\begin{abstract}
The gold and tin-bearing alluvial placers of the Brazilian Amazon high terrains constitute a remarkable record of the environmental changes which occurred in the region during the Quaternary. The deposits are typically immature, and have been formed by mass movements under semi-arid climate. They are clearly older than the last rain forest spreading, and may be attributed to cyclic episodes which have been correlated to the Pleistocene glaciations.

These interpretations are highlighted by the discovery of abundant polished stone artifacts which have been preserved within Pleistocene deposits. The archeological record allows the demarcation of an important cultural tradition, widely disseminated in the Brazilian Amazon, and gives a starting point to review our present knowledge of the Amazonian Prehistory - still centered in studies on the "varzea" region, of Holocene age. This means that the human establishment in the Amazon is much older than formerly believed.
\end{abstract}

\section{INTRODUCTION}

The practice of alluvial mining on important mineral provinces in the Brazilian Amazon allows the proposition of a new geological approach for those Quaternary placers. The studied areas are well distributed in both cratonic portions of the Amazon, as shown in Figure 1.

This results in a comprehensive outline of the high terrains which border the Amazonian

\footnotetext{
Instituto de Geociências, UnB - Curso de Poss-Graduaçăo, 70910-Brasilia, DF, Brazil.
} 


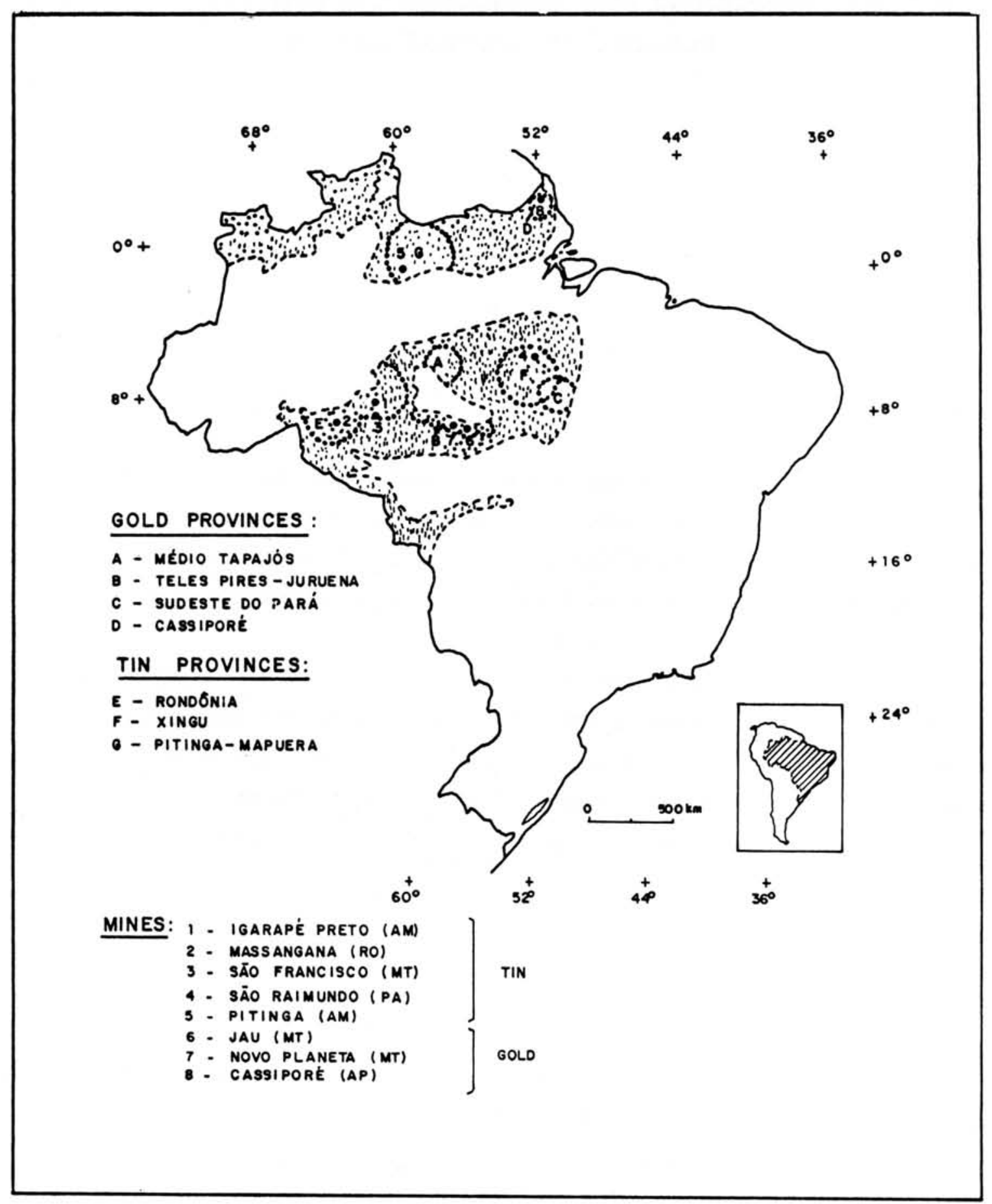

Figure 1 - Localization on the studied areas. 
Plain, involving large poorly explored areas of the Brazilian Territory. The data come from several mines, research areas and "garimpos" of gold and tin, most of them in production.

\section{GEOLOGICAL SETTING}

The alluvial deposits which have been studied in the Amazon high terrains constitute a remarkable record of the environmental changes which occurred in the region during the Quaternary, as pointed out by VEIGA et al. (1988). The placers lie along valleys of 4 th to 6 th orders streams (SolimõesAmazonas River: 1st order), representing, as a rule, extremely immature deposits - thus departing from the classical alluvial model which has been proposed elsewhere. They are several kilometers long, and 100 to $1.000 \mathrm{~m}$ wide, with thickness varying from 2 to $10 \mathrm{~m}$.

These Amazonian placers develop close to its sources lying over flat to slightly undulated terrains, and are usually covered by the tropical forest. They are associated to streams with low transport and sorting capacity, which accumulate immature sediments generally settled as a single layer with graded bedding (see Fig. 2).

The sediments are very clayish, with angular fragments of variable grain size and unstable minerals. These features are typical of sediments submitted to short transportation under torrential conditions, and rapid deposition without significant reworking. They result from mass movement processes by lateral apport of colluvial sediments which fill up the valleys (see Fig. 3).

Such processes take place under semi-arid climate, conditioned by torrential rains concentrated over well-defined periods. The vegetal cover which dominates under these conditions is scarce, facilitating erosion and a rapid settling of a large volume of immature sediments. On the other hand, the conditions prevailing under humid climate are that of deep chemical weathering associated with the spreading of dense jungle, which favour the formation of thick regoliths.

\section{PALEOENVIRONMENTAL EVOLUTION}

The paleoenvironmental evolution of the intertropical regions during the Quaternary can be correlated with the occurrence of glacial cycles at the high-latitude regions. As the atmospheric temperature decreases, the advance of glaciers from the polar regions implies lower sea levels (about - 100 $\mathrm{m}$, in the last glaciation), together with the installation of a dryer climate in the tropics.

SIOL (1985) outlines the major changes that could have taken place in the Amazon: the advent of a dryer climate had caused a retrocession of the rain forest, the confined to ciliary forests, with 


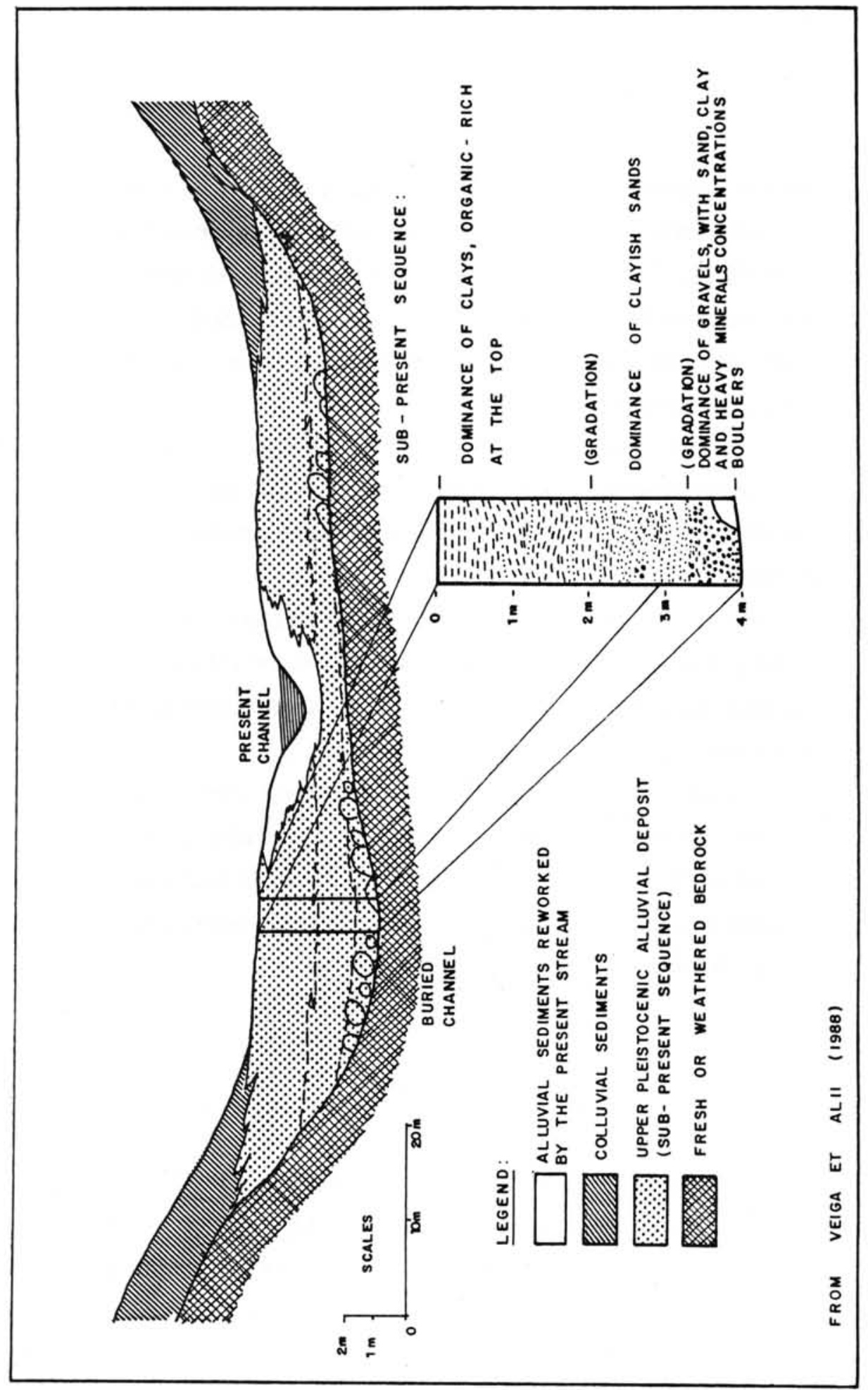

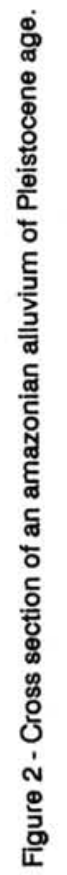




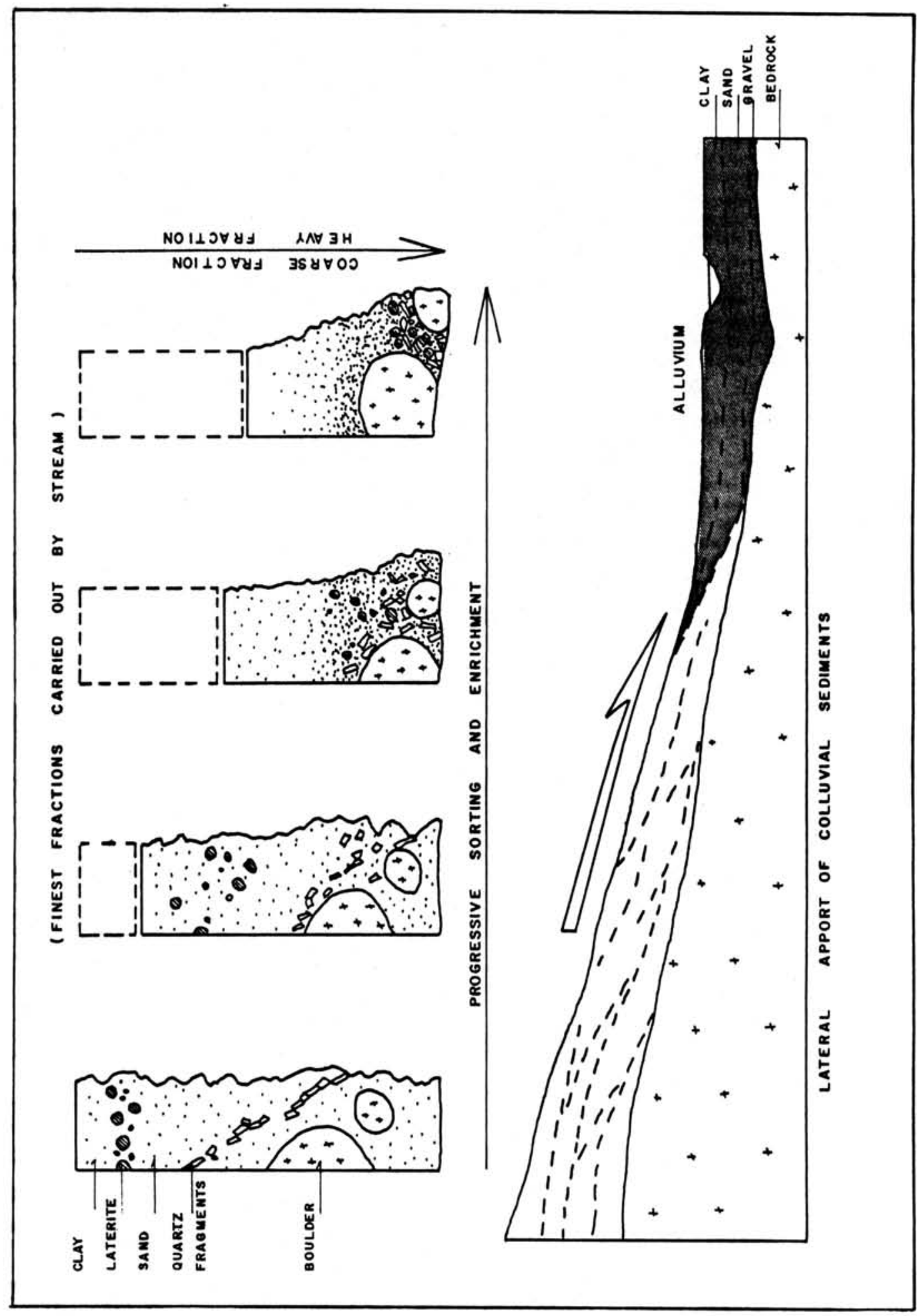

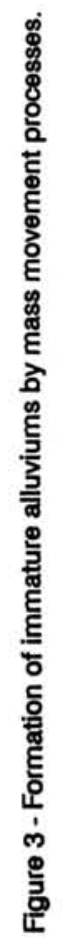


expansion of the savanna-like vegetation - as indicated by palynological analysis in the peripherical regions of the Amazon. Thus the glacial periods had reflected in the Amazonian high terrains through the occurrence of expressive mass movements, with the filling up of the existing valleys by a large volume of immature sediments. During the interglacial periods, under more humid climate, there was a major tendency to reinstate the forest cover and to form thick regoliths.

We may conclude, therefore, that the alluvial deposits in the Amazonian high ground valleys were formed before the present forest, whose last expansion had started about 10,000 years B.P. between the Pleistocene and the Holocene -, at the decline of the last glaciation. In the same way, we can correlate the older alluvial sequences which have been reeognized in the region to the former glaciations, as proposed to the buried paleovalleys of the Rondonia Tin Rrovince (PAYOLLA et al., 1984), and to the terraces of Pitinga region, described by DAOUD \& VEIGA (1986).

Thus we can define the following sequences of alluvial deposits, as indicated in the Fiqure 4: (a) a former sequence, attributed to the Middle Pleistocene; (b) a sub-present sequence, attributed to the Upper Pleistocene; and (c) a present sequence, associated with the early Holocene spreading of the rain forest, and developed by reworking of the Pleistocene sediments by the present streams. Between 4,000 and 2,000 years B.P., a new period of relatively dry climate seems to have locally favoured downslope movement of colluvial masses, covering part of the preexistent alluviums.

\section{ARCHEOLOGICAL RECORD}

These interpretations are highlighted by the discovery of abundant archeological record, such as lithic instruments, which have been preserved within the Pleistocene deposits. We can often see well-elaborated artifacts of polished stone - axes, percussion and scraping tools - of homogeneous design and finishing, culturally different from the ceramic traditions which have been recognized in the region (see Fig. 5). The artifacts are made of selected materials - often diabase, or other fine-grained rocks - which occur in some cases tens of kilometers far from the source rocks.

The occurrence of those artifacts and some polishing factories, buried beneath the subpresent sediments - which had been settled under semi-arid climate and may be correlated to the last glacial period, finished about 11,000 years B.P. - allows the demarcation of an important cultural tradition, widely disseminated in the Brazilian Amazon. The definition of this stratigraphic setting in the high ground gives a starting point to review our present knowledge of the Amazonian Prehistory - still centered in studies on the varzea region, of Holocene age. This means that the human establishment in the Amazon is much older than formely believed.

In fact, archaeological sites older than 11,000 years tend to be only tound, in the 


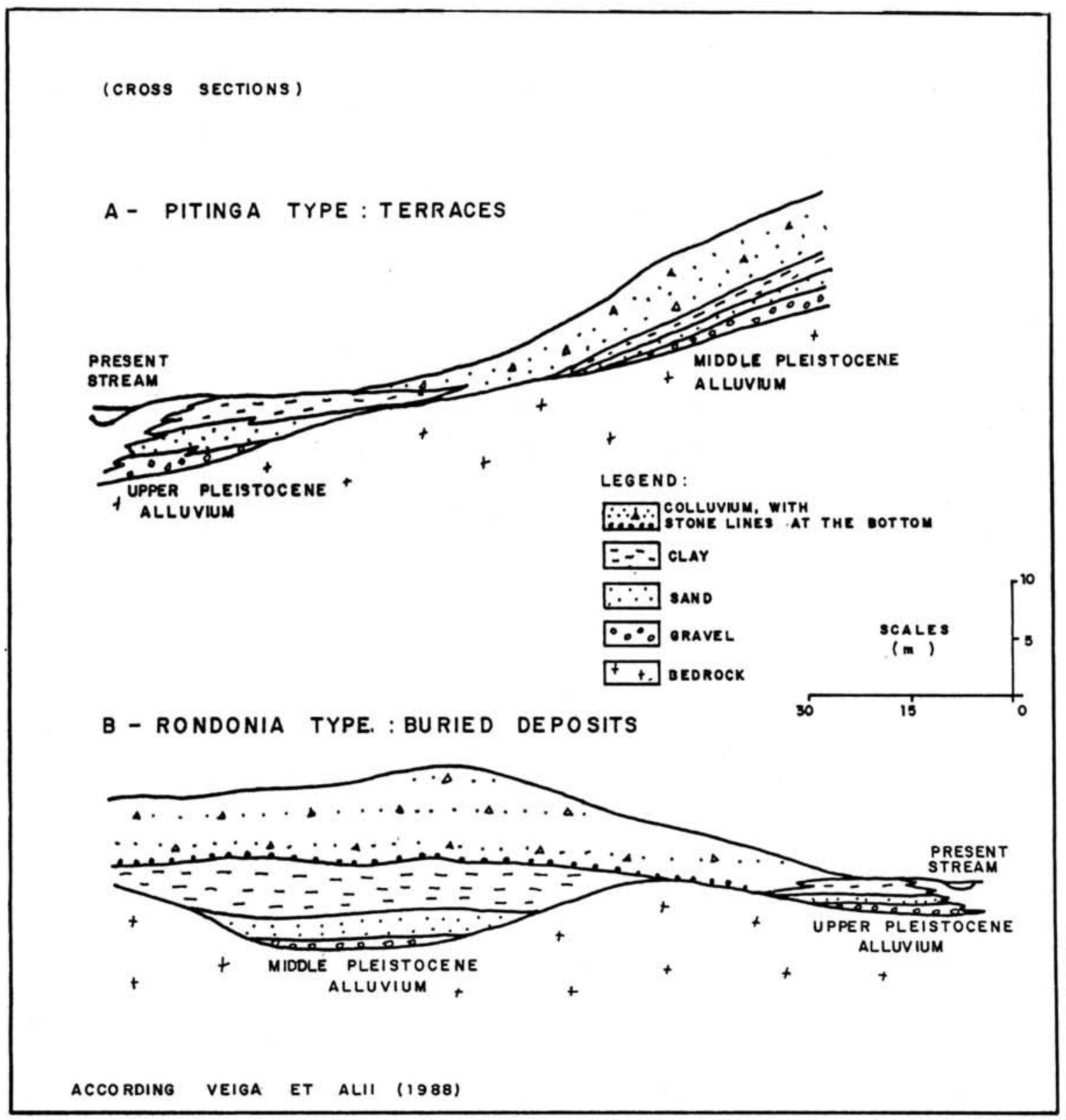

Figure 4 - Stratigraphy of amazonian alluvial deposits of Pleistocene age. 

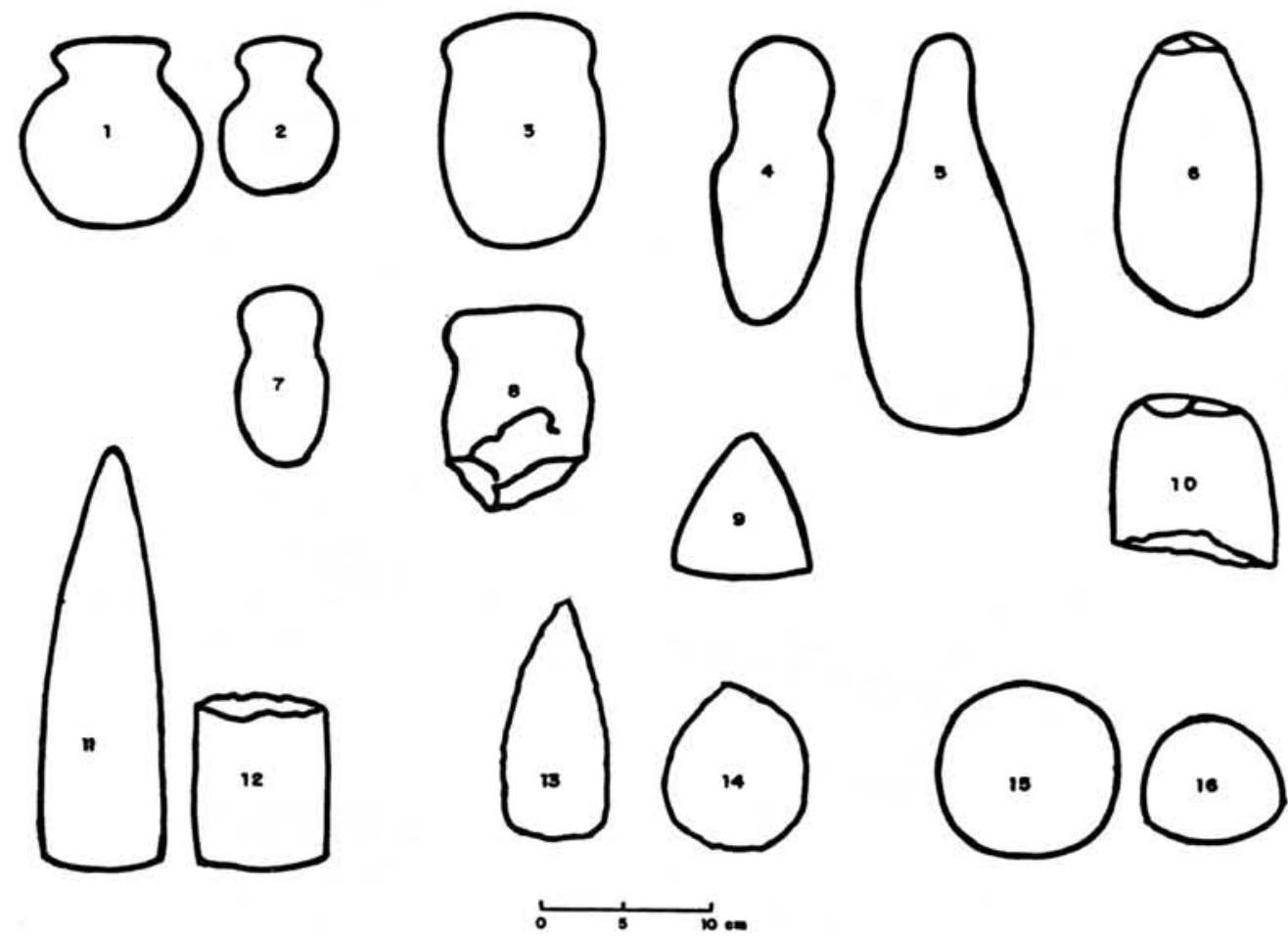

Figure 5 - Examples of stone artifacts found within the Upper Pleistocene alluvial sediments.

Description of the stone artifacts:

1 and 2: Diabase round axes (or scrapers), from Novo Planeta region (see map).

3: Diabase axe from Pitinga region.

4: Diabase axe from Novo Planeta region.

5: Diabase scraper from Pitinga region.

6: Amphibolite axe from São Raimundo region (Xingu river).

7: Diabase scraper from Novo Planeta region.

8: Fragment of diabase axe from Cassipore region. Compare with number 3.

9: Diabase "prism" from Novo Planeta region.

10: Fragment of diabase axe from Cassiporé region. Compare with number 6.

11: Diabase pestie from Pitinga region.

12: Fragment of granulite pestle from Massangana region. Compare with number 11.

13: Granite pestle from Pitinga region.

14: Diabase axe (or scraper) from lgarape Preto region.

15 and 16: Diabase "wheels" from Pitinga region. 
Amazon, far from the influence of major rivers. The last post-glacial sea level rise has account for the damming up of the major-Amazonian rivers (such as the Solimões-Amazonas), with a consequent widespread clayish sedimentation which have deeply buried former strata and perhaps existing archeological sites. The rivers with little suspendend load - as the Negro and the Tapajós - produced only restricted sedimentation zones. However, the water level rise would submerge the settlements occasionally present along the river margins.

The high ground archeological record represent in this way an expressive increase in our knowledge of the Amazonian Prehistory. The dominant use of polishing technology may be indicative of relatively sedentary hunter-gatherers groups, living the beginnings of the agricultural practices. Regarding the large geographical distribution and the frequence and similarity of the artifacts, its difusion is very wide and homogeneous, and suggests a long-term human occupancy, rather than a sporadic permanence.

A multidisciplinary reexamination of the Amazon Prehistory may result in a significative contribution to the reconstitution of the Prehistory of the continent as a whole. The Amazon seems to have an important role in the first stages of colonization of the South America, acting as a natural way between the Middle America, the Northern Andean region and the Middle-South and the Northeast of Brazil. It is remarkable that the record which have been decribed in those areas (WÜST \& MENEZES, 1984 and NARANJO, 1985), are notably like to the artifacts found in the Amazon. On the other hand, the possible link between our polishers and the rupestrian artistic traditions known in the region is a subject worth of further research.

Some of the polished stone objects seem to have been episodically incorporated by the present-day indians both in the utilitary and in the mythological sense - but without continuity of this old technological tradition. A hiatus of thousand of years - between the disappearence of the paleoamerindians and the colonization by the succeeding rain forest inhabitants - may have coincided with a period of major technological evolution in the Near East, without analogies in the South America.

The lack of continuity in the Amazonian Holocene record let us to correlate the disappearence of this preceramic tradition with the major environmental changes at the end of the Last Glaciation. The forest spreading seems to have caused an insurmountable obstacle to those paleoamerindians, as well as to several faunal species then extinct. Nevertheless, the archeological remains are indicative of a long history of human occupation in the Amazon, which have been submmitted to massive environmental changes during the Quaternary - as demostrated by the geological record in the high ground Pleistocene alluviums.

\section{ACKNOWLEDGEMENTS}


The author gratefully acknowledges the stimulant discussions and permanent aid recelved from colleagues who have been also occupied - and preoccupied - with a better understanding of the Amazonian reality, particularly during this times of rapid and weak-controlled changes: Elmer Prata Salomão, Wilson Godoy Falleiros, Walid El Koury Daoud, Fernando Latorraca, Marcel Auguste Dardenne and Othon Henry Leonardos.

\section{REFERENCES}

DAOUD, W.E.K. \& VEIGA, A.T.C. (1986) Geologia dos aluviőes estanfferos da mina de Pitinga - AM. In: CONGRESSO BRASILEIRO DE GEOLOGIA, 34, Goiânia, 1986. Anais. Goiânia, SBG. v.5, p.2048-2061.

NARANJO, P. (1985) Plantas alimentícias del Ecuador precolombino. Interciência, 10(5):227-235.

SIOL, H. (1985) Amazônia: fundamentos da ecologia da maior região de florestas tropicais. Petrópolis, Ed. Vozes. 72p.

VEIGA, A.T.C.; DARDENNE, M.A.; SALOMÃO, E.P. (1988) Geologia dos aluviões aurfferos e estanfferos da Amazônia. In: CONGRESSO BRASILEIRO DE GEOLOGIA, 35., Belém, 1988. Anais. Belém, SBG. v.1, p.164-177.

WŨST, I. \& MENEZES, V.B. (1984) Tecnologia e arte das sociedades pré-coloniais brasileiras. In: FUNDAÇÃO BIENAL DE SÃO PAULO. Tradição e ruptura: exposição e síntese de arte e cultura brasileira. São Paulo, FBSP. p.9-21. 